\title{
Status of Common Bean (Phaseolus vulgaris L.) Diseases in Metekel Zone, North West Ethiopia
}

\author{
Tizazu Degu*, Wasihun Yaregal, Tesfaye Gudisa \\ Ethiopian Institute of Agricultural Research, Pawe Research Center, Ethiopia
}

\begin{abstract}
Common bean has versatile benefits such as nutritional, environmental and economic benefits for the producers and consumers. However, its production has been affected and threatened by a number of biotic factors. Survey was conducted in 2018/19 cropping season within three woredas of Metekel Zone, Benshangul-Gumz region, Ethiopia, with the objective of identifying and prioritizing haricot bean diseases. The result revealed that haricot bean production in the Zone is affected by eleven diseases which are caused by fungi, bacteria and virus. Based on the disease severity, incidence and prevalence scores, the diseases are categorized in to Major, intermediate and Minor disease. Angular Leaf Spot (Pseudocercospora griseola), Anthracnose (Colletotrichum lindemuthianum), Floury leaf spot (Mycovellosiella phaseoli), and Cercospora leaf spot (Cercospora cruenta are grouped in to major diseases. Rust (Uromyces appendiculatus), Web blight Rhizoctonia solani Kühn (teleomorph Thanatephorus cucumeris (Frank) Donk), Ascochyta blight (Phomaexigua var. exigua/Ascochyta phaseolorum acc) and Bean common mosaic virus (potyvirus) are categorized as Intermediate and the remaining three diseases: Halo blight (Pseudomonas syringaepv. phaseolicola), Common Bacterial Blight (Xanthomonas axonopodis pv phaseoli) and Downy Mildew (Phytophthora phaseoli Thaxt) are grouped under minor diseases. The survey revealed, the common bean production and disease management practices and variety development efforts for the Zone, onwards, should focus on those major disease (such as Angular Leaf Spot, Anthracnose, Floury leaf spot, and Frog Eye leaf spot) in order to sustain production and productivity of common bean cultivars.
\end{abstract}

Keywords: Common bean; Diseases; Metekel; Pawe; Mandura; Ethiopia

\section{INTRODUCTION}

In 2016/17 cropping season, in Ethiopia, common bean covered 290,202 hectares of land, and harvested 4,839,227 quintals of produce with productivity of 16.7 quintals per hectare and it was produced by around 4 million head house hold farmers in Ethiopia [1]. The crop has versatile uses and has versatile benefits such as nutritional, environmental and economic benefits for the producers and consumers.

Although the crop has a huge benefit, its production has been affected and threatened by a number of biotic and abiotic factors. Drought, soil acidity, soil fertility reduction, and climate change are some of the challenges. In addition, Pests (ball worm), diseases which are caused by fungi, bacteria, virus are the biotic factors which limit haricot bean production.

Worldwide rust, anthracnose and angular leaf spot are reported to have wide distributions [2]. In Ethiopia, Common bean suffers from a wide range of leaf, stem and root diseases such as common bacterial blight (CBB), rust, anthracnose, angular leaf spot, web blight and bean common mosaic virus. Among them, Common bacterial blight, rust, and anthracnose are the most important and widely distributed than angular and floury leaf spot [3], while the others though important, are much more restricted in their distribution [4]. Tesfaye, reported that, anthracnose, rust, common bacterial blight, angular leaf spot, ascochyta blight, and bean common mosaic virus are the most important in the country [5]. In the central Rift valley, rust, common bacterial blight and anthracnose are reported to occur simultaneously, at different degrees [3].

Diseases in common bean are known to reduce quality of harvested seed, germinability, and market value of the seed. In addition, depending on incidence, severity disease occurrence, production system and management practice applied, environmental condition, cultivars used and crop stage affected, average yield loss ranged

Correspondence to: Tizazu Degu, Ethiopian Institute of Agricultural Research, Pawe Research Center, Ethiopia, Tel: +251913188204; E-mail: tizazudegu@gmail.com

Received: February 26, 2020; Accepted: April 16, 2020; Published: April 23, 2020

Citation: Degu T, Yaregal W, Gudisa T (2020) Status of Common Bean (Phaseolus vulgaris L.) Diseases in Metekel Zone, North West Ethiopia. J Plant Pathol Microbiol 11:494. doi: 10.35248/2157-7471.20.11.494

Copyright: (C) 2020 Degu T. This is an open-access article distributed under the terms of the Creative Commons Attribution License, which permits unrestricted use, distribution, and reproduction in any medium, provided the original author and source are credited. 
between $20 \%$ and $100 \%$ [6]. Usually, more than two diseases occur together in the same field, thus aggravate the problem. Moreover, pathogens of Angular Leaf spot, Anthracnose, Common Bacterial Blight, Halo Blight, Bacterial Brown Spot, and Bean Common Mosaic Virus are well known to transmit through seeds. Thus, the infected seeds are the primary source of inoculums for the disease. Seedborne fungi are also the principal producers of mycotoxins [7].

Worldwide haricot bean is affected by more than forty-eight $(>48)$ diseases. However, in Ethiopia, few diseases have been reported and documented. The number of diseases would have been increased, if surveys were conducted thoroughly in every production zones of the country. The previous surveys were concentrated in the southern and southwestern parts of the country. So, in this survey, the northern western part of the country was covered was having objective of identifying and prioritizing haricot bean diseases. The result prioritized four diseases to be targeted and develop strategies to control angular leaf spot, Anthracnose and floury leaf spot and Cercospora leaf spot in North western Ethiopia.

\section{MATERIALS AND METHODS}

\section{Area description}

The survey area is located in Metekel zone of the Benshan gulgumz regional state of Ethiopia. It has an estimated area of $51,000 \mathrm{~km}^{-2}$ and is located in the north-western part of Ethiopia. Metekel Zone, the study area, is the largest zone in the regional state, with an area of $26,272 \mathrm{~km}^{-2}$ followed by Assosa (14,166 sq. km), and Kamashi $(8,850$ sq. $\mathrm{km})$ [8]. The Zone, occupy $>50 \%$ in the area coverage, and $60 \%$ in grain crop Production in the Benshangulgumz Administrative region [1]. It has Seven woredas and haricot bean is produced in all woredas. More than 40 types of crops are cultivated in the Zone, the most important ones in terms of area coverage are maize, finger millete, sorghum, groundnut, sesame, common bean, Nug, Tef, pepper and soybean. These crops cover the largest proportion of land in the three surveyed Woredas. The major haricot bean producing woredas are Dibate, Bullen, Dangur and Mandura, followed by Wonbera, Pawe and Guba, respectively. Haricot bean is produced as sole crop, and as rotational crop after finger millet, maize, groundnut and sesame, and as intercrop with maize and sorghum in the cropping system, in the Zone. The survey was conducted by purposively selecting three woredas/districts (such as Dibate, Bullen and Mandura).

Dibate woreda, has an altitude of $1550 \mathrm{~m}$. It received mean annual rain fall of $1072 \mathrm{~mm}$. Its mean annual temperature is in the range $25-29^{\circ} \mathrm{C}$ (Table 1 ). Rain begins mostly in April or May ending in October/November. Bush haricot bean varieties are cultivated with major and also the climbing types are also cultivated by the local inhabitants (mostly by Gumuz people). The inhabitants serve in their dish as 'Nifro' and 'shiro'.

Bullen woreda has an altitude of $1450 \mathrm{~m}$. The area received 1643.4 $\mathrm{mm}$ mean annual amount of rainfall. It has mean maximum Temperature of $27.9^{\circ} \mathrm{C}$ and with minimum temperature of $14.7^{\circ} \mathrm{C}$ (Table 1). Mostly the rain starts in May and almost ends in October. Both climbers and bush beans are grown in the Woreda.

Mandura woreda has an altitude of $1350 \mathrm{~m}$ a.s.l. It received high amount of mean annual rainfall of $2030.3 \mathrm{~mm}$. And It has mean maximum daily temperature of $33.4^{\circ} \mathrm{C}$ and with minimum daily temperature of $18.1^{\circ} \mathrm{C}$. The main rainy usually starts in May and Mostly ends in October (Table 1). In Mandura, climbing bean varieties usually are dominant in the 'woreda' and are grown in farmyards usually trained with bamboo [9].

\section{RESEARCH METHODOLOGY}

Based on the availability of suitable field for the survey, it was conducted along the main road at 5 to $10 \mathrm{~km}$ interval in the right and left of the main road. Three to five sampling points per field were selected in a diagonal or "W" fashion. At each sampling point five randomly selected plants were selected for assessing and estimating the severity of the diseases in percentage, and ten (10) consecutive plants in a row were taken to assess and estimate the incidence of diseases. A total of 15 to 25 plants per field for severity and 30 to 50 plants per field used to estimate incidence, respectively.

Disease severity is defined as the affected leaf area, including the lesion and associated chlorosis (i.e. the non-green area) as a percentage of total leaf area. Most the survey data were collected at around pod filling stages. It estimates how much portion of the total leaf area is infected by the disease and it has more direct effect on yield. Disease incidence is the number of plants infected with the disease as a percentage of total plants, and expressed in percentage. It estimates and shows how many plants are infected over the total plants. Prevalence is the proportion of the disease infected based on the locality (field) and is expressed in percentage. It shows how much the disease is spread over the production area. The severity, incidence, and prevalence in the survey was calculated by the following formula:

$$
\begin{aligned}
& \text { Severity }=\left(\frac{\text { Infected area of the sample plant }}{\text { Total area of a sample plan }}\right) \times 100 \\
& \text { Incidence }=\left(\frac{\text { Numberofinfectedplantsinthesamplingunit }}{\text { Totalnumberofplantsinthesamplingunit }}\right) \times 100 \\
& \text { Prevalence }=\left(\frac{\text { Numberoffieldswithdiseaseinfectioninthesurveyedarea }}{\text { TotalNumberoffieldsthesurveyed }}\right) \times 100
\end{aligned}
$$

Haricot bean varieties used: There are two types of varieties (bushy and running/pole varieties) are produced in the area. More than 40 varieties of common bean are known to be developed in the country. Most farmers in the area utilize three old bushy cultivars such as Nasir (the dominant), Awash-Melka and Awash-1 and few farmers cultivate recently released varieties such as (ser-119, ser-125). In addition to these varieties, runner types of locally cultivated perennial haricot bean varieties are used and produced in the area. They are produced nearby their home and inside the forest area. Since, those varieties require support, the trees used as a support for its production. Climbers (runners) are planted along fences and on the borders of maize fields [9]. The survey was conducted in the farmers' field which grows the bushy type varieties.

\section{RESULTS AND DISCUSSION}

The survey revealed that haricot bean production in Meteke Zone is affected by eleven diseases caused by fungi, bacteria and virus (Table 2). Eight of them were fungal diseases (such as Angular Leaf spot, Anthracnose, Frog eye leaf spot, Rust, Web blight, 
Table 1: Rainfall, maximum and minimum temperature of 6 years (between 2006 and 2017)* of Bullen, Dibate and Mandura, Woreda.

\begin{tabular}{|c|c|c|c|c|c|c|c|c|c|c|c|c|c|c|}
\hline \multirow{2}{*}{ Climate } & \multirow{2}{*}{ Woredas } & \multicolumn{12}{|c|}{ Months } & \multirow{2}{*}{$\begin{array}{l}\text { Total/ } \\
\text { Mean }\end{array}$} \\
\hline & & Jan & Feb & Mar & Apr & May & Jun & Jul & Aug & Sep & Oct & Nov & Dec & \\
\hline \multirow{3}{*}{$\begin{array}{l}\text { Rain fall } \\
(\mathrm{mm})\end{array}$} & Bullen & 4.7 & 3.3 & 1.5 & 72.4 & 153.1 & 270.9 & 317.5 & 381.4 & 303.2 & 124.6 & 9.2 & 1.5 & 1643.4 \\
\hline & Dibate & 3.4 & 1.8 & 15.5 & 27.2 & 92.3 & 163.4 & 228.1 & 264.1 & 197.4 & 65.9 & 11.8 & 1.6 & 1072.4 \\
\hline & Mandura & 0.4 & 0.7 & 8.9 & 46.4 & 171.1 & 450.2 & 539.6 & 389.2 & 298.2 & 95.8 & 33.7 & 2.5 & 2030.4 \\
\hline \multirow{3}{*}{$\operatorname{Max}\left({ }^{\circ} \mathrm{C}\right)$} & Bullen & 29.9 & 31.3 & 32.4 & 30.9 & 27.9 & 25.4 & 24.1 & 24.1 & 25.2 & 26.8 & 28.0 & 28.8 & 27.9 \\
\hline & Dibate & 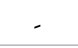 & - & - & - & 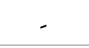 & - & - & - & - & - & - & - & - \\
\hline & Mandura & 34.6 & 37.0 & 37.4 & 37.7 & 36.0 & 33.2 & 30.8 & 28.8 & 29.5 & 31.2 & 32.0 & 32.7 & 33.4 \\
\hline \multirow{3}{*}{$\operatorname{Min}\left({ }^{\circ} \mathrm{C}\right)$} & Bullen & 11.6 & 13.7 & 16.9 & 17.5 & 16.5 & 15.7 & 15.5 & 15.1 & 15.1 & 14.3 & 12.6 & 12.4 & 14.7 \\
\hline & Dibate & - & - & - & - & - & - & - & - & - & - & - & - & - \\
\hline & Mandura & 20.3 & 20.7 & 22.3 & 21.8 & 20.6 & 17.5 & 15.3 & 15.2 & 15.6 & 15.4 & 15.9 & 16.6 & 18.1 \\
\hline
\end{tabular}

"." = Data not obtained, "*"=Some data in between are misses.

Table 2: Pest status of haricot-bean diseases (based on incidence, severity and prevalence) in Metekel zone.

\begin{tabular}{ccccc}
\hline S. No. & Disease & Pathogen & Cause & Status \\
\hline 1 & Angular Leaf Spot & Pseudocercospora griseola & Fungus & Major \\
\hline 2 & Anthracnose & Colletotrichum lindemuthianum & Fungus & Major \\
\hline 3 & Floury leaf spot & Mycovellosiella phaseoli & Fungus & Major \\
\hline 4 & Cercospora leaf spot & Cercospora cruenta & Fungus & Major \\
\hline 5 & Rust & Uromyce appendiculatus & Fungus & Intermediate \\
\hline 6 & Web blight & Rhizoctoniasolani Kühn (teleomorph Thanatephorus cucumeris & Fungus & Intermediate \\
\hline 7 & Ascochyta blight & Phomaexigua var. exigua/Ascochyta phaseolorum Sacc) & Fungus & Intermediate \\
\hline 8 & Bean common mosaic virus & Potyvirus & Virus & intermediate \\
\hline 9 & Halo blight & Pseudomonas syringaepv. Phaseolicola & Bacterium & Minor \\
\hline 10 & Common Bacterial Blight & Xanthomonas axono podispv phaseoli & Bacterium & Minor \\
\hline 11 & Downy Mildew & Phytophthora phaseoli Thaxt & Fungus & Minor \\
\hline
\end{tabular}

Cercospora Leaf Spot, Aschochita Blight and downy mildew); two of them are bacterial (Common bacterial blight, Halo blight); and one of them is viral disease (i.e. Common mosaic virus). Based on the disease severity, incidence and prevalence scores, the diseases can be categorized in to three i.e. Major, intermediate and minor diseases. Angular Leaf Spot, Anthracnose, Floury leaf spot, and Cercospora leaf spot can be grouped as Major. Rust, Web blight, Ascochyta blight and Bean common mosaic virus can be categorized as Intermediate and the remaining three diseases Halo blight, Common Bacterial Blight and Downy Mildew categorized as minor (Table 2). Disease prevalence, incidence and severity varied among the surveyed woredas. The distribution, incidence, severity and prevalence of all observed diseases are indicated in Table 3 below.

\section{Angular Leaf Spot (ALS)}

The Angular Leaf spot disease was having an average prevalence of $100 \%$, incidence of 85.5 and severity of $20.6 \%$ in the zone. The prevalence of $100 \%$ indicates that the disease was existed in every surveyed fields. The highest disease incidence score of $96.3 \%$ was obtained in Mandura Woreda, followed by Dibate Woreda with $86.8 \%$. ALS disease severity was highest at Dibate (22.0\%) followed by at Mandura Woreda (18.3\%) (Table 3). Similarly, Getachew and Habtamu [10] reported the disease with variable severities in different districts (i.e. $61 \%$ at Burjdi, of $41 \%$ at Konso, $29 \%$ at
Demba Gofa and 14\% at Mihirab Arbaya Districts). Getachew and Habtamu [10], associated the high disease severity with altitude range of below 2000 m.a.s.l., poorly prepared farms, farm saved and local market seed sources, intercropping, early planting, low level of fertilizer application and with high weed.

In the present survey, comparatively low ALS incidence and severity was obtained at Bullen. This can be attributed to the climatic factor, pathogenic variability, host factor and general management of the field. It is the major disease in hot humid areas of the countries. This survey proved that angular leaf spot (ALS) to be the major bean diseases. Rezene et al. [11], reported high pathogenic diversity of ALS with 21 races (Pathotypes) (Pseudocercospora griseola) and two of them (63:59 and 19:33) were reported widely distributed. Different authors reported its high probability occurrence of ALS inoculums throughout the season in abundant amount in hot humid areas like Metekel zone [3,12].

A yield loss that reached up to $80 \%$ had been reported on susceptible common bean genotypes under severe conditions of infection [6]. Mongi [13], reported yield losses of up to $61 \%$ in Southern Tanzania. Stenglein et al. [14], reported that for every $10 \%$ increase in ALS severity results in $7.9 \%$ yield loss. Fikre et al. [15], reported, for every $1 \%$ increase in ALS severity results in 13 to $125 \mathrm{~kg} / \mathrm{ha}$ yield loss, depending on the cultivar. ALS together with Rust resulted in loss of $54 \%$ yield [16]. The major mechanism 
Table 3: Disease severity incidence and prevalence of common bean diseases in 'weredas' of Metekel Zone, Ethiopia, in 2018 cropping season.

\begin{tabular}{cccccccccccccc}
\hline \multirow{2}{*}{ Diseases } & \multicolumn{3}{c}{ Mandura } & \multicolumn{3}{c}{ Dibate } & \multicolumn{3}{c}{ Bullen } & \multicolumn{3}{c}{ Metekel Zone } \\
\cline { 2 - 13 } & Sev. & In. & Pre. & Sev. & In. & Pre. & Sev. & In. & Pre. & Sev. & In. & Pre. \\
\hline ALS & 18.3 & 96.3 & 100.0 & 22.0 & 86.8 & 100.0 & 11.7 & 53.7 & 100.0 & 20.6 & 85.1 & 100.0 \\
\hline CBB & 0.0 & 0.0 & 0.0 & 0.6 & 3.0 & 13.3 & 0.0 & 0.0 & 0.0 & 0.5 & 2.3 & 5.3 \\
\hline Ant & 6.7 & 33.3 & 50.0 & 17.6 & 69.4 & 86.7 & 14.2 & 79.6 & 100.0 & 15.8 & 65.4 & 74.7 \\
\hline FELS & 9.5 & 85.2 & 100.0 & 7.8 & 56.9 & 73.3 & 14.2 & 57.4 & 100.0 & 8.6 & 60.8 & 89.3 \\
\hline Rust & 0.0 & 0.0 & 0.0 & 3.0 & 23.6 & 53.3 & 1.7 & 11.1 & 50.0 & 2.5 & 19.3 & 31.3 \\
\hline WB & 0.0 & 0.0 & 0.0 & 17.3 & 66.7 & 93.3 & 11.7 & 77.8 & 100.0 & 14.4 & 58.6 & 57.3 \\
\hline CMV & 0.0 & 0.0 & 0.0 & 8.8 & 25.7 & 60.0 & 5.8 & 29.6 & 100.0 & 7.3 & 22.6 & 44.0 \\
\hline FLS & 5.8 & 35.9 & 100.0 & 2.4 & 18.3 & 46.7 & 5.0 & 46.3 & 100.0 & 3.1 & 23.2 & 78.7 \\
\hline Ascochita & 11.5 & 61.1 & 100.0 & 5.4 & 32.4 & 66.7 & 4.2 & 18.5 & 100.0 & 6.1 & 35.1 & 86.7 \\
\hline DM & 0.0 & 0.0 & 0.0 & 0.3 & 2.1 & 6.7 & 0.0 & 0.0 & 0.0 & 0.2 & 1.6 & 2.7 \\
\hline HB & 5.0 & 10.0 & 33.3 & 5.0 & 2.0 & 5.5 & 4.0 & 10.0 & 33.0 & 4.8 & 6.8 & 22.1 \\
\hline
\end{tabular}

Note: Sev.=Severity; In. $=$ Incidence; Pre. $=$ Prevalence; ALS=Angular Leaf Spot; CBB=Common Bacterial Blight; Ant=Anthracnose; FELS=Frog Eye Leaf Spot; Rust; WB= Web Blight; CMV=Common Mosaic Virus; FLS= Flory Leaf Spot; Ascochita=Aschochita Blight; DM=Dawny Mildew; HB= Halo Blight.

of yield reduction of ALS is leaf defoliation and fastens maturity period, it consequently reduces seed size and yield [15].

The primary source of ALS infection is considered to be infested seed [17] (Cardona- Alvarez and Walker, 1956). It spread within and among fields by wind-blown particles of infested soil, and wind-blown and rain-splashed spores. In addition, crop debris, volunteer crops and off season bean crops are sources of inoculum [16]. Infected seeds and plant debris are the main source of infection for ALS, so the use of resistant varieties, use of clean seed, burial of infected debris and rotation can decrease the severity. In Ethiopia, five resistant common bean genotypes (EMP-233, EMP212, G-10843 and Dicta-65, and NZBR-2-2) has been identified by Fikre and Abush [18].

\section{Common Bacterial Blight (CBB)}

The mean $\mathrm{CBB}$ disease occurrence in the surveyed area was insignificant (Table 3 and Figure 1). The average prevalence was $5.3 \%$, the incidence was $2.3 \%$ and severity was $0.5 \%$. The disease was obtained only in Dibate Woreda, with insignificant prevalence of $13.3 \%$, incidence of $3 \%$ and with severity of $0.6 \%$. The existence of the disease in the other two woredas was not confirmed in this survey. However, the high exchange of seeds among the farmers within the zone and absence of quarantine among the woredas, will make it easy for the disease to be introduced and established in the other woredas. Tesfaye [19], reported, CBB distribution to be high in cooler areas where rainfall is erratic. He obtained, high level of the disease in central rift valley with semi-arid agro ecology, and intermediate level of the disease in Eastern Ethiopia with sub moisture agro ecology and low levels of the disease in semi humid and Moist areas (Jimma, Metu, Hararghe, and Melkassa) [19].

When common bean is exposed to extended period of warm and humid weather, CBB can be highly destructive and causes losses in yield and seed quality, it can result in $22.4 \%$ yield loss in Eastern part of Ethiopia [20]. Opio et al. [21], reported, estimated losses due to CBB to be $10-40 \%$ on susceptible cultivars in Uganda. The disease has been reported in many parts of Ethiopia.

The pathogens of CBB overwinters in seed, bean debris, and weeds [22]. It can be effectively managed with use of genetic resistance

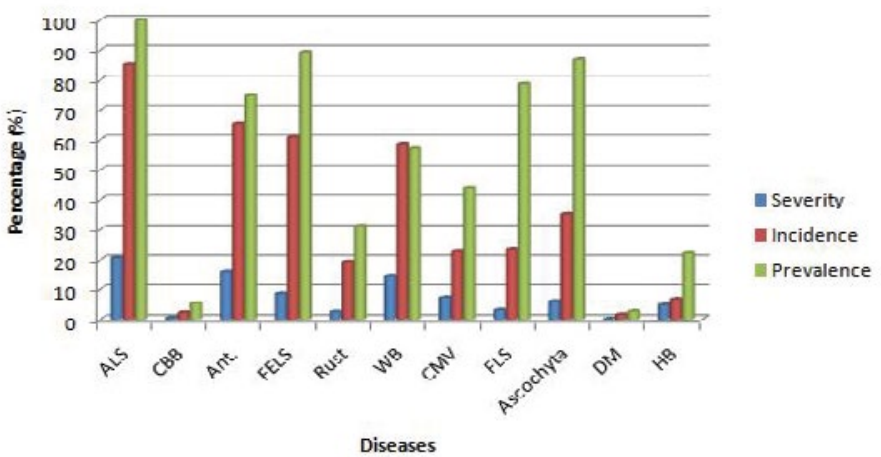

Figure 1: Disease severity incidence and prevalence in Metekel Zone, North West Ethiopia, in 2018 cropping season.

[23] plus use of certified seed, crop rotation, and field sanitation. Kidane [24], reported seed treatment with streptomycin enhanced yield by $15.6 \%$ over untreated control; and foliar application of Kocide-101 significantly increased yield of common bean varieties by approximately $18.5 \%$ at Melkassa and Arsi Negelle over unsprayed control. He also revealed, yield gain between $27.0 \%$ and 38.0\% at Melkassa and between 27.6\% and 36.1\% at Arsi Negelle by integrated application of seed treatment of streptomycin with twice and once foliar sprays of Kocide 101.

\section{Anthracnose (Ant)}

Anthracnose is one of the most important diseases of common bean in Ethiopia. It occurred with prevalence of $74.7 \%$, incidence of 65.4 and severity of 15.8 , in the surveyed woredas. The survey revealed the variability of the disease from 50 to $100 \%$ in prevalence. The disease (Anthracnose) heavily attached the crop in Bullen wereda with $100 \%$ prevalence, with $79.6 \%$ incidence and with $15.8 \%$ severity scores, followed by Dibate, with $86.7 \%$ prevalence, $69.4 \%$ incidence and $17.6 \%$ severity scores. So, anthracnose is an important disease in the three woredas. Habtu et al. [3], reported Anthrachnose to be widely distributed and economically the most important in Ethiopian and high plant density and high weediness has associated with high anthracnose in the Rift Valley.

Similarly, Tesfaye [19], obtained anthracnose in all surveyed areas, with high incidence at Bako, Didessa, Ambo, Arsi-Negele, Meki 
and Areka. He also reported high severity of bean anthrachnose in the humid zone (H2) and high incidence to be associated to semiarid (SA) zones. In agreement with this report, the surveyed area receives annual rain fall between 1072 and $2030 \mathrm{~mm}$ and mean minimum and Maximum rainfall of $16.4^{\circ} \mathrm{C}$ and $37^{\circ} \mathrm{C}$. This result is consistent with previous reports that anthracnose is more severe in regions with high rainfall and moderate temperature.

Wide Variability i.e., 14 races of the pathogen has been reported and two of them were reported to have wide distribution. These reported races are 63, 65, 68, 73, 81, 128, 296, 465, 511, 589, 961 and 1027 [19]. Races $128 \& 511$ were reported common and were having wide distribution. Roba-1 variety was found to be resistant registered variety in Ethiopia [25]. In Ethiopia, anthracnose has shown to reduce yield up to $70 \%$ [26].

\section{Cercospora leaf spot}

Cercospora leaf spot is also one of the most important disease of haricot bean in Metekel zone. Its distribution expressed in prevalence was $89.3 \%$ in the zone but it was $100 \%$ at Mandura and Bullen woredas, and $73.3 \%$ in Dibate (Table 3 and Figure 1). The disease severity and incidence score was 8.5 and 60.8 , in the zone. The high disease incidence was scored at Mandura (85.2\%) and Bullen (57.4\%) Woreda. The mean severity score ranged between 9.5 (at Mandura) and 14.2 (at Bullen) (Table 3).The reason for high incidence, severity, and prevalence in the zone and in Mandura in particular might be connected toits management practices in the area.

Cercospora leaf spot, caused by Cercospora cruenta and C. canescens, causes severe leaf spotting and defoliation during the time of flowering and pod formation. It can use different hosts such as cowpea, green grams and soybean [27]. The pathogen can survive in infected seeds and in surface debris in the field for extended periods [28]. Involvement of different species in causing cercospora leaf spot complicates characterization of species. Yield losses of $50 \%$ in severely diseased field have been reported [27]. Pande et al. [29], reported use of disease fee seeds, field sanitation, crop rotation, destruction of infected crop debris, and avoiding alternate hosts near the crop may help in reducing the incidence.

\section{Rust}

Common bean rust, is caused by Uromyces appendiculatus (Pers.) Unger, was obtained in Dibate and Bullen woreda but not in Mandura Wereda. It was occured with less than $50 \%$ prevalence, $19.3 \%$ incidence and $2.5 \%$ severity in the zone. Relatively, rust is more important at Dibate than the other woredas. Habtu [30], reported, rust to be the production constraint in Ethiopia. Tesfaye [19], reported low level of rust in humid and sub-humid (Bako) agro ecologies and intermediate level of rust in sub-humid and moist agro-ecologies (Jimma, Metu, Hararghe, and Melkassa). Similarly, Habtu et al. [3], reported variability of rust occurrence to based on location, weed management and plant density. They revealed high disease intensity at Sidama Zone, to be associated with low plant density and low weediness.

Long distance dissemination of rust inoculum is mainly by wind [31]. However, short distance dissemination may occur through contaminated farm implements, clothing and insects [16]. Habtu et al. [32], reported yield losses varied based on level of resistance of varieties, intensity of the rust, location and season. They demonstrated, yield loss ranged between 43 and $85 \%$ at Ambo and Debrezeit on susceptible and $30 \%$ in partially resistant variety. Pastor-Corrales and Liebenberg reported high severities of rust occurs in cool $\left(17-22^{\circ} \mathrm{C}\right)$ and humid (>95\% humidity) environment). Wortmann et al. [33] reported an estimated yield loss of 191,400 metric tonnes per annum in Africa.

Mersha and Hau [34] reported the disease to be favored by cool to moderate temperatures, high moisture, infected plant debris and volunteer plants, cultural practices, late planting, herbicide damage, excess nitrogen or hail damage. Repeated disease cycles may occur at 10 to 14 -day intervals under favourable conditions. The disease can be managed by the use of crop rotation, deep ploughing of infected debris, early planting and use of resistant varieties [35]. Resistant varieties are widely used to control ALS and rust diseases of common beans [14]. However, their use is often limited because of high pathogen variability in the field.

\section{Web blight}

Web blight has high prevalence at Bullen (100\%) and Dibate (93.3\%), with the incidence of 77.8 and 66.7 , and severity score 11.7 , and 17.3 respectively. It is one of the potential diseases in Metekel zone. It was previously reported by Mohammed et al. [36], at the same location. The disease favoured by hot humid weather and moderate temperature.

Web blight (WB) of common bean (Phaseolus vulgaris L.) is caused by aerially dispersed isolates of Rhizoctonia solani Kühn (teleomorph Thanatephorus cucumeris (Frank) Donk) resulting in defoliation and pod infection which leads to mild to severe yield and seed quality losses. The pathogen spreads by airborne basidiospores, mycelial bridges between plants, rain-splashed sclerotia, infested soil debris, and infected seeds. It is reported to be problematic in East Africa [37].

The WB pathogen, R. solani (Rs), is a complex species composed of subgroups within Anastomosis Groups. At least six subgroups of Rs cause symptoms of web blight [38]. Variability among these sub-groups includes different virulence patterns, fungicide resistance, optimal growth temperature and epidemiology (disease development rate, fungal propagule type, dissemination and survival).

\section{Bean common mosaic virus}

BCMV is caused by potyvirus has high prevalence of $100 \%$ at Bullen, with $77.8 \%$ incidence and $11.7 \%$ severity (Table 3 and Figure 1). In addition, the $60 \%$ prevalence, $25.7 \%$ incidence and $8.8 \%$ severity makes it an intermediately important disease.

BCMV has worldwide occurrence and reported to cause $50-70 \%$ yield loss [39]. It is a non-persistent, aphid-transmitted potyvirus and distributed nearly in every country where beans are grown. Primary source of infection occurs through infected seed that ensures the wide dispersal of the virus became seed production programs in many countries. Drijfhout [40] reported BCM was first reported in 1899 by Iwanoski in Russia. The presence of aphid vectors and susceptible cultivars aggravates the problem by the disease [39].

Use of disease resistance cultivars, use of pathogen-free seed which certified by appropriate seed agencies, production of seeds in 
pathogen unfavorable environment [39], and vector management are importance BCMV disease management strategy.

\section{Downy mildew}

Dawny mildew is reported to be caused by Phytophthor aphaseoli Thaxt, is one of the minor diseases in Metekel zone. It was obtained with prevalence of $2.7 \%$, severity of $0.2 \%$ and incidence of $1.6 \%$ and only obtained in Dibate woreda, with prevalence of $6.7 \%$, severity of 0.3 and incidence of $2.1 \%$. It is the first report in Ethiopia.

Evening dews and leaf wetness provide ideal conditions for the development of downy mildew and reported to have six races [41]. P. phaseoli has been reported to overwinter as oospores on infected lima bean and are the primary inoculum, with the secondary inoculum being sporangia [42]. Oospores may produce germ tubes and infect the plant directly or may produce sporangia. A report of the disease on common bean is scarce and further survey and confirmation is needed.

\section{Floury leaf spot}

Floury Leaf Spot is one of the most important diseases of haricot bean in Ethiopia. It occurred with high prevalence of $78.7 \%$, incidence of 23.3 and severity of 3.1, in the surveyed Zone. The prevalence of $100 \%$ at Bullen and Mandura Woreda whereas with $46 \%$ in Dibate. The disease incidence of $46 \%$ was higher at Bullen followed by 35.9 and 19.3 at Mandura and Dibate respectively. The disease severity scores were higher at Mandura and Bullen with 5.8 and $5.0 \%$ respectively. So, Floury Leaf Spot is one of the most important diseases in the three woredas. Similar to this report Tesfaye [19], reported floury leaf spot to be highly prevalent in the warm and humid regions of the country.

\section{Aschochyta leaf blight}

It is one of the most important diseases in Metekel zone. It occurred with prevalence of 86.7 , severity of 35.5 and incidence of $6.1 \%$ in the zone. Prevalence of $100 \%$ was recorded at Mandura and Bullen woreda. The incidence and severity of attack at Mandura was $61.1 \%$ and $11.5 \%$, respectively, was higher than that of Bullen and Dibatse. The least disease severity (of $32.4 \%$ ) and incidence (of $5.8 \%)$ score was obtained at Dibatse.

It is one of haricot bean fungal diseases caused by the fungus Phoma exigua var. exigua $=$ Ascochyta phaseolorum. Trapero-Casas and Kaiser [43], reported disease progression occur from $5^{\circ} \mathrm{C}$ to $25^{\circ} \mathrm{C}$ with an optimum temperature of $16-20^{\circ} \mathrm{C}$, and a minimum of 6 hours of leaf wetness. Disease severity increases with the increase in relative humidity. Tivoli and Banniza [44], reported cloudiness and prolonged wet weather favour rapid development and spread of the disease. The symptoms involve large dark grey to black spots that later become zonate with concentric rings around the spot. Stems when infected the nodes are blackened and premature leaf drop may occur. Pod infection can result into formation of cankers and results in seed infection. The pathogen survives on infected or contaminated seeds and infected plant debris [45]. Integration of cultural methods, fungicides and use of resistant genotypes are the effective methods of control the disease [27].

\section{Halo blight}

Halo blight, caused by Pseudomonas syringae pv Phaseolica, is one of the least important diseases in Metekel zone. It was obtained with prevalence of $22.1 \%$, severity of $6.8 \%$ and incidence of $4.8 \%$. The extent of attack at Mandura and Bullen woredas were higher than that of Dibatse Woreda. High humidity and cool temperatures favours disease development [46].

Habtu [4], reported four races (races 1, 2, 3, and 4) of Pseudomonas syringae pv. phaseolicola from Ethiopian collections. Taylor et al. [47], reported nine races ( 1 to 9$)$ and five (2, 4, $6 \& 7$ ) of them were Ethiopian isolates. Worldwide, a number of races (1, 2, 5, 6 and 7) were distributed with race 6 being pre-dominant.

The disease can cause discoloration, shriveling and contamination of seeds. So, seeds are the major source of infection. Serious losses due to HB have been documented in Lesotho, Rwanda and Zimbabwe while yield losses of $43 \%$ have been reported in experimental conditions [46]. Deep ploughing, crop rotation, use of clean seeds, use of resistant varieties and use of fungicides are recommended for the disease.

\section{CONCLUSION}

The survey revealed that haricot bean production in Meteke Zone is affected by eleven diseases caused by fungi, bacteria and virus. Majorities (Eight) of them are fungal diseases, two of them are bacterial and one is viral disease. Based on the disease severity, incidence and prevalence scores, the diseases are categorized in to Major, intermediate and Minor disease. Angular Leaf Spot, Anthracnose, Floury leaf spot, and Frog Eye leaf spot are grouped as Major. Rust, Web blight, Ascochyta blight and Bean common mosaic virus are categorized as Intermediate and the remaining three diseases: Halo blight, Common Bacterial Blight and Downy Mildew are grouped under minor diseases. So, in common bean production, the disease management practices and variety development efforts in the Zone, onwards, should focus on those major diseases (Angular Leaf Spot, Anthracnose, Floury leaf spot, and Frog Eye leaf spot) in order to sustain production and productivity of common bean cultivars.

\section{ACKNOWLEDGMENT}

The research was financed by Ethiopian Institute of Agricultural Research (EIAR). The authors acknowledge Pawe Agricultural Research Center for provision of facilities and financial administration. We also acknowledge the technical assistances and researchers in Low Land Pulse crops program for their support in data collection. We also acknowledge researchers and facilitators in the Ambo Research Center.

\section{REFERENCES}

1. Central Statistical Agency. Agricultural sample survey report on area and production of major crops. (2016/2017); 1:118

2. Schwartz HF, Galvez GE. Bean production problems. CIAT, Cali, Colombia. Seed Services. 1980;2000:11-1197.

3. Habtu A, Sachet I, Zadoks JC. A survey of cropping practices and foliar diseases of common beans in Ethiopia. Crop Protection. 1996;15(2):179. 186.

4. Habtu A. Research highlights on haricot bean diseases 'in Ethiopia. 
In: Proceedings of National Workshop on haricot bean Research in Ethiopia: An assessment of status, progress, priorities and strategies. Addis Ababa, Ethiopia. 1990;50-53.

5. Tesfaye B. Loss assessment study on haricot bean due to anthracnose. Pest Management 111 Journal of Ethiopia. 1997;3:9-18.

6. Singh SP, Schwartz HF. Breeding common bean for resistance to diseases: A review. Crops Science. 2015;50:2199-2223

7. Yesuf M. Seedborne Nature of Colletotrichum lindemuthianum and its epidemic on common beans in the major bean growing areas of Ethiopia. A thesis submitted in partial fulfilment of the requirements for the Degree of Doctor of Philosophy (Tropical Agriculture), Kasetsart University. Pp. 142.

8. Adugna A. Ethiopian demography and health [Internet]. Assosa, Ethiopia. 2014.

9. Fissaha Z. Component analysis and genotype $\mathrm{X}$ environment interaction of haricot bean (Phaseolus vulgaris L.) in Metkel Zone. A thesis submitted to the School of Graduate Studies, Alemaya University. 2004;79

10. Gudero G, Terefe H. Distribution and relative importance of common bean angular leaf spot in subsistence farming systems in Southern Ethiopia. Pest Management Journal of Ethiopia. 2019;21:35-55

11. Rezene Y, Tesfaye K, Clare M, Gepts P. Pathotypes characterization and virulence diversity of Pseudocercospora griseola the causal agent of angular leaf spot disease collected from major common bean (Phaseolus vulgaris L.) growing areas of Ethiopia. Journal of Plant Pathology Microbiology. 2018;9:445.

12. Beshir T. Research on anthracnose disease of haricot bean in Ethiopia. Proceedings, 1st Pan-African Working Group Meeting on Anthracnose of Beans. Ambo, Ethiopia. 1991;51-54.

13. Mongi RJ. Breeding for resistance against angular leaf spot disease of common bean in the Southern Highlands of Tanzania. Ph.D. Dissertation, College of Agriculture and Science, University of KwaZulu Natal, Pietermaritzburg Campus, Republic of South Africa. 2016;223.

14. Stenglein SL, Ploper D, Vizgarra OP, Balatti P. Angular leaf spot: A disease caused by the fungus Phaeoisariopsis griseola (Sacc.) Ferrarison Phaseolus vulgaris L. Advances in Applied Microbiology. 2003;52:209243.

15. Lemessa F, Sori W, Wakjira M. Association between Angular leaf spot (Phaeoisariopsis griseola (Sacc.) Ferraris) and common bean (Phaseolus vulgaris L.) Yield loss at Jimma, Southwestern Ethiopia. Plant Pathology Journal. 2011;10(2):57-65

16. Pamela P, Mawejje D, Ugen M. Severity of angular leaf spot and rust diseases on common beans in Central Uganda. Uganda Journal of Agricultural Sciences. 2014;15(1): 63-72.

17. Cardona-alvarez C, Walker JC. Angular leaf spot of bean. Phytopathology. 1956;46:610-615.

18. Lemessaand F, Tesfaye A. Evaluation of bean (Phaseolus vulgaris) genotypes for multiple resistance to angular and floury leaf spot diseases. Trop. Sci. 2005;45,63-66.

19. Tesfaye B. Biology and Control of Bean Anthracnose in Ethiopia. A $\mathrm{PhD}$ thesis submitted in fulfillment of requirements for the degree of Doctor of Philosophy in the Faculty of Natural and Agricultural Sciences, (Plant Pathology), University of the Free State Bloemfontein, South Africa. 2003;144.

20. Fininsa C. Relationship between common bacterial blight severity and bean yield loss in pure stand and maize bean intercropping. International Journal of Pest Management. 2003;49:177-185.

21. Opio AF, Teri JM, Allen DJ. Assessment of yield losses caused by common bacterial blight of beans in Uganda. African Crop Science Journal. 1992;1:59-67.

22. Mkandawire ABC, Mabagala RB, Guzmán P, Paul Gepts P, Gilbertson RL. Genetic diversity and pathogenic variation of Common Blight Bacteria (Xanthomonascam pestrispv. phaseoli and X. mpestrispv. phaseoli var. fuscans) Suggests pathogen coevolution with the common Bean. Phytopathology. 2004;94:593-603.

23. Fourier D, Herselman L, Mienie C. Improvement of common bacterial resistance in South African dry beans cultivar Teebus. African Crop Science Journal. 2001;(19)4:377-386.

24. Tums K. Integrated management of common bacterial blight of common bean through host resistance and chemical applications in the Central Rift Valley, Ethiopia. MSc. Thesis Submitted To College of Agriculture, Department of Plant Science, School of Graduate studies, Haramaya University. 2007;66.

25. Tesfaye B. Determination of the diversity of Colletotrichumlinde muthianum (Sacc. \& Magn.) B \& C in Ethiopia. Pest Management Journal of Ethiopia. 1999;3:77-82.

26. Fitsum S, Mohammed A, Selvaraj T, Negeri M. Field management of Anthracnose (Colletotrichum lindemuthianum) in common bean through foliar spray fungicides and seed treatment bioagents. Science Technology and Arts Research Journal. 2014;3(2):19-25.

27. Pande S, Sharma M, Kumari S, Gaur PM, Chen W, Kaur L, et al. Integrated foliar diseases management of legumes. International Conference on Grain Legumes: Quality Improvement, Value Addition and Trade, February. Indian Society of Pulses Research and Development, Indian Institute of Pulses Research, Kanpur, India. 2009.

28. Kilpatrick RA. Longivity of Cercospora kikuchii on soybean stems. Phytopathology. 1956;46:58

29. Pande S, Sharma M, Rao JN. Etiology, biology and management of diseases of food legumes. p. 1-15. In: Food Legumes for Nutritional Security and Sustainable Agriculture. M.C. Kharkwal (ed). Proceedings of the Fourth International Food Legumes Research Conference (IFLRC-IV), October 18-22, 2005, New Delhi, India. 2007.

30. Habtu A. Epidemiology of bean rust in Ethiopia. PhD Thesis Wageningen, UK. 1994.

31. Habtu A, Abiy T, Zadoks JC. Analysing crop loss in a bean rust pathosystem: I Disease Progress, Crop growth, and Yield loss. Pest Management Journal of Ethiopia. 1997;1:9-18.

32. Wortmann CS, Kirkby RA, Eledu CA, Allen DJ. Atlas of common bean (Phaseolus vulgaris L.) production in Africa. CIAT, Cali, Colombia. 1998;133.

33. Mersha Z, Hau B. Effects of bean rust (Uromyces appendiculatus) epidemics on host dynamics of common bean (Phaseolus vulgaris). Plant Pathology. 2008;(57) 4,674-686

34. Ochichi PB. Effect of cropping systems on the occurrence of fungal and bacterial diseases of legumes in Western Kenya. Msc. Thesis in Microbiology, University of Nairobi. 2015;118.

35. Mohammed K, Zelalem F, Mulugeta A. Report on survey of major bean diseases in Metekel zone. Pawe Agricultural Research Centre. 2002;4-6.

36. Godoy-Lutz G, Arias J, Steadman JR, Eskridge KM. Role of natural seed infection by the web blight pathogen in common beans, seed damage, seedling emergence and early disease development. Plant Disease. 1996;80:887-890.

37. Godoy-Lutz G, Kuninaga S, Steadman JR, Powers K. Phylogenetic analysis of Rhizoctoniasolani subgroups associated with web blight symptoms on common bean based on ITS-5.8s rDNA. Journal of General Plant Pathology. 2008;74:32-40. 
38. Brick MA, Grafton KF. Improvement of Medium-Seeded Race Durango Cultivars. In: Common Bean Improvement in the TwentyFirst Century (Ed). Springer Science+Business Media Dordrecht, USA. 1999;405.

39. Drijfhout E, Silbernagel MJ, Burke DW. Differentiation of strains of bean common mosaic virus. Netherlands Journal of Plant Pathology. 1978;84:13-26.

40. Davidson CR. Studies of Phytophthora phaseoli, causal agent of lima bean downy mildew including race assessment, transformation, growth characteristics and varietal response. M.S. thesis. University of Delaware, Newark. 2002.

41. Wester RE, Goth RW, Drechsler C. Overwintering of Phytophthoraphaseoli. Phytopathology. 1996;56:95-97.

42. Trapero-Casas A, Kaiser WJ. Development of Didymellarabiei, the teleomorph of Ascochytarabiei on chickpea straw. Phytopathology. 1992;82:1261-1266.
43. Tivoli B, Banniza S. Comparison of the epidemiology of ascochyta blights on grain legumes. European. Journal of Plant Pathology. 2007;119:59-76.

44. Gossen BD, Hwang SF, Conner RL, Chang KF. Managing the Ascochyta blight complex on field pea in Western Canada. Prairie Soils and Crops Journal. 2011;4,135-141.

45. Fourier D. Distribution and severity of bacterial diseases on dry beans (Phaseolus vulgaris L.) in South Africa. Journal of Phytopathology. 2002;150:220- 226

46. Taylor JD, Teverson DM, Allen DJ, Pastor-Corrales MA. Identification and origin of races of Pseudomonas syringae pv. Phaseolicola from Africa and other bean growing areas. Plant Patholog. 1996;45: 469-478

47. Allen DJ, Buruchara RA, Smithson JB. Diseases of common bean. In: Allen DJ, Lenne JM (eds), The Pathology of Food and Pasture Legumes. CAB International, Wallingford, UK. 1998; 179-235. 